\title{
ANALISIS PERILAKU PENGGUNA SISTEM INFORMASI PENGELOLAAN NILAI RAPOR MENGGUNAKAN METODE UTAUT
}

\author{
${ }^{1)}$ Megawati, ${ }^{2)}$ Wanda Afita \\ ${ }^{1,2)}$ Program Studi Sistem Informasi, Fakultas Sains dan Teknologi UIN Suska Riau \\ Jl. HR Soebrantas KM.18 Panam Pekanbaru - Riau \\ E-Mail :megawati@uin-suska.ac.id,wandaafita@students.uin-suska.ac.id
}

\begin{abstract}
ABSTRAK
Perkembangan teknologi informasi yang luas mendorong berbagai instansi maupun sekolah untuk menerapkan teknologi informasi yang sesuai, salah satunya adalah SMPN 1 Tualang. SMPN 1 Tualang telah menerapkan sistem informasi pengelolaan nilai rapor sejak tahun 2015 yang berguna untuk mempermudah guru dalam mengelola nilai rapor siswa. Permasalahan yang terjadi selama penerapannya yaitu terjadi error dalam penginputan nilai, masih terdapat guru yang belum mengerti cara menginput nilai siswa dan menyuruh guru lain untuk menginputkan nilai kedalam sistem, serta terjadinya server down saat hari-hari terakhir penutupan sistem. Tujuan penelitian ini adalah untuk mengetahui faktor-faktor yang paling mempengaruhi minat berperilaku pengguna berdasarkan variabel UTAUT yang terdiri dari performance expectancy, effort expectancy, social influence, facilitating conditions dan dimoderasi oleh variabel gender, age dan experience. Hasil penelitian ini menunjukkan bahwa faktor-faktor yang paling mempengaruhi minat perilaku pengguna yaitu effort expectancy sebesar $68,5 \%$, facilitating conditions sebesar $62,7 \%$ dan performance expectancy sebesar 56,6\%. Sedangkan variabel moderator gender, age dan experience mempengaruhi minat pengguna sebesar 79,0\%. Serta diperoleh hasil dari kesenjangan antara ekspektasi pihak sekolah dengan persepsi pengguna sebesar - 0,9 . Untuk mengatasi $G A P$ pihak sekolah harus melakukan evaluasi dan monitoring mengenai penerapan sistem informasi pengelolaan nilai rapor pada SMPN 1 Tualang.
\end{abstract}

Kata Kunci: sistem informasi, pengelolaan nilai rapor, SMPN 1 Tualang, UTAUT

\begin{abstract}
The development of extensive information technology has encouraged various agencies and schools to apply appropriate information technology, one of which is Tualang 1 Public Middle School. Tualang 1 Public Middle School has implemented a report card management information system since 2015 that is useful to facilitate teachers in managing student report cards. Problems that occur during implementation are errors that occur in inputting values, there are still teachers who do not understand how to input the value of students and tell other teachers to input values into the system, and the server down during the last days of system closure. The purpose of this study was to determine the factors that most influence interest in user behavior based on UTAUT variables which consist of performance expectancy, effort expectancy, social influence, facilitating conditions and moderated by variables of gender, age and experience. The results of this study indicate that the factors that most influence interest in user behavior are effort expectancy of $68.5 \%$, facilitating conditions of $62.7 \%$ and performance expectancy of $56.6 \%$. While the moderator gender, age and experience variables affect user interest by $79.0 \%$. As well as the results obtained from the gap between school expectations and user perceptions of -0.9. To overcome GAP the school must conduct evaluation and monitoring regarding the application of information systems for report card management at Tualang 1 Public Middle School.
\end{abstract}

Keyword: information system, management of report cards, SMP 1 Tualang, UTAUT

\section{PENDAHULUAN}

Perkembangan teknologi informasi yang luas mendorong berbagai instansi maupun sekolah untuk menerapkan teknologi informasi yang sesuai untuk meunjang kegiatan operasional mereka, SMPN 1 Tualang telah menerapkan Sistem Informasi Pengelolaan Nilai Rapor yang berguna untuk mempermudah guru dalam mengelola nilai rapor siswa. Sistem rapor ini telah digunakan sejak tahun 2015 yang dikhususkan untuk siswa dengan kurikulum 2013. Model Kurikulum 2013 mengharuskan guru membuat dua nilai seperti nilai besar (1100) dan nilai kecil (1-4), dengan sistem ini guru hanya mengolah atau menginput nilai besar nya saja seperti nilai pengetahuan, keterampilan dan perilaku lalu sistem yang 
akan memproses nilai tersebut menjadi nilai kecil.

Sistem informasi pengelolaan nilai rapor diterapkan dengan tujuan untuk mempermudah guru dalam mengelola nilai rapor siswa dengan harapan mampu meningkatkan kinerja guru dalam pekerjaannya, namun kenyataan yag terjadi saat ini sistem belum sepenuhnya sesuai dengan harapan pengguna. Saat penginputan nilai masih terjadi error pada sistem, terdapat nilai yang kosong setelah diinputkan, kemudian masih ada guru yang belum mengerti cara menginput nilai siswa. Hal ini karena tidak ada nya buku petunjuk penggunaan sistem (manual book) dan pelatihan hanya dilakukan satu kali saat sistem pertama kali diterapkan yang mengakibatkan kekurang pahaman pengguna sehingga masih ada sebagian guru yang menyuruh guru lain untuk menginputkan nilai ke dalam sistem. Sistem down saat hari-hari terakhir penutupan sistem karena banyaknya guru atau user secara bersamaan mengakses sistem informasi pengelolaan nilai rapor, gangguan jaringan menyebabkan sistem tidak dapat diakses untuk beberapa waktu.

Untuk itu penulis menawarkan penyelesaian masalah dengan menerapkan metode Unified Theory of Acceptance and Use of Technology (UTAUT). UTAUT adalah sebuah teori penerimaan teknologi informasi dengan tujuan untuk memberikan kriteria atau variabel yang mempengaruhi IT acceptance oleh user [1]. Terdapat empat konstruksi utama yang memainkan peran penting sebagai determinan langsung dari minat untuk berperilaku (behavioral Intention) dan perilaku untuk menggunakan suatu teknologi (use behavior). Adapun penerimaan pengguna yang diukur dalam metode ini adalah ekspektasi kinerja (performance expectancy), ekspektasi usaha (effort expectancy), pengaruh sosial (social influence) dan kondisi pendukung (facilitating conditions) yang di moderatori oleh gender, age, dan experience.

\section{Perilaku Pengguna}

Perilaku adalah tindakan-tindakan (action) atau reaksi-reaksi dari suatu objek atau organisme. Perilaku dapat berupa sadar (concious) atau tidak sadar (unconcious), terusterang (overt) atau diam-diam (convert), sukarela (voluntary) atau tidak sukarela (involuntary) [2].

\section{Minat Berperilaku (Behavioral Intention)}

Minat keperilakuan teknologi informasi (behavioral intetntion) didefinisikan sebagai tingkat keinginan atau minat pemakai menggunakan sistem secara terus menerus dengan asumsi bahwa mereka mempunyai akses terhadap informasi. Seorang akan berminat menggunakan suatu teknologi informasi yang baru apabila pengguna tersebut meyakini dengan menggunakan teknologi informasi tersebut akan meningkatkan kinerjanya, menggunakan toknologi informasi dapat dilakukan dengan mudah dan pengguna tersebut mendapatkan pengaruh lingkungan sekitarnya dalam menggunakan teknologi informasi tersebut.

\section{Unified Theory of Acceptance and Use of Technology (UTAUT)}

UTAUT merupakan sistem audit informasi tentang perilaku pengguna terhadap teknologi.[3]. Sedangkan UTAUT menurut (Venkatesh, dkk, 2003) merupakan sebuah model untuk menjelaskan perilaku pengguna terhadap teknologi informasi. Model ini merupakan salah satu model penerimaan teknologi terkini yang dikembangkan dengan mensintesis elemen-elemen pada delapan model penerimaan teknologi terkemuka untuk memperoleh kesatuan pandangan mengenai penerimaan pengguna.[4]

Terdapat empat konstruk utama dalam model UTAUT yang memainkan peran penting 
sebagai determinan langsung dari behavioral intention dan use behavior yaitu, performance expectancy, effort expectancy, social influence, dan facilitating conditions. [5]. Disamping itu terdapat pula empat moderator: gender, age, voluntariness, dan experience yang diposisikan untuk memoderasi dampak dari empat konstruk utama pada behavioral intention dan use behavior.

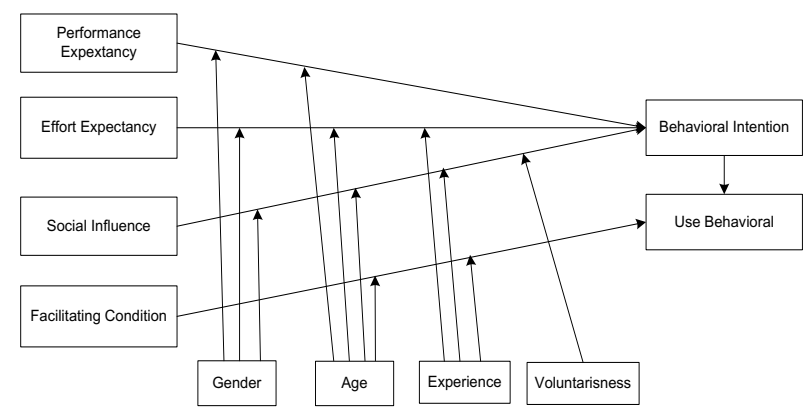

Gambar 1. Model UTAUT [1]

\section{Analisis GAP}

Gap analisys atau analis kesenjangan merupakan salah satu langkah yang sangat penting dalam tahapan perencanaan maupun tahap evaluasi kerja. Metode ini merupakan salah satu metode yang paling umum digunakan dalam pengelolaan manajemen internal suatu lembaga. Secara harfiah "gap" mengidentifikasikan adanya suatu perbedaan (disparity) antara satu hal dengan hal lainnya. Gap analisys sering digunakan di bidang manajemen dan menjadi salah satu alat yang digunakan untuk mengukur kualitas pelayanan (quality of service).

\section{METODE}

\section{Kerangka Kerja Penelitian}

Adapun proses dalam melakukan penelitian ini digambarkan dalam sebuah flowchart pada Gambar 2.

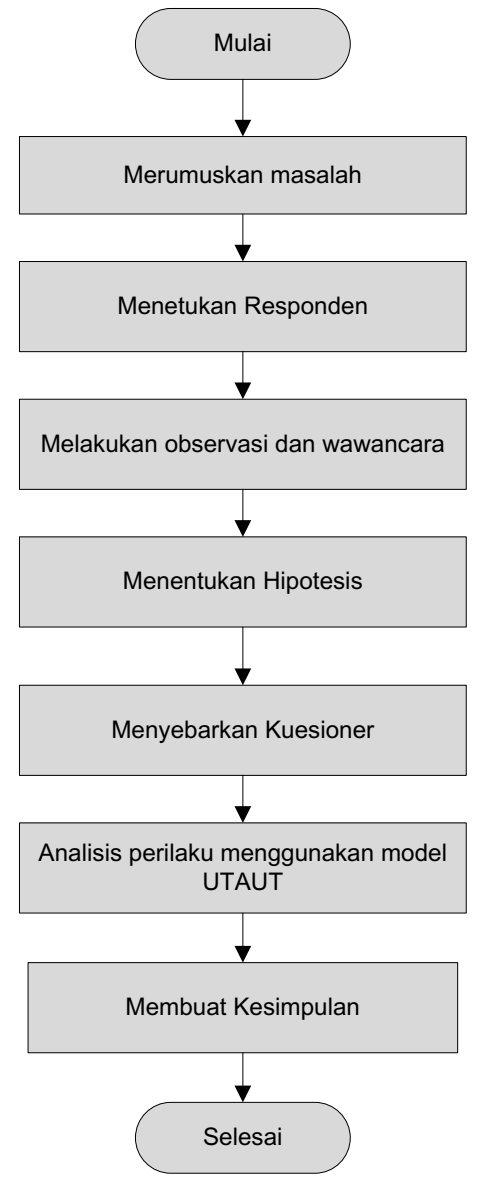

Gambar 2. Kerangka Kerja Penelitian

\section{Merumuskan Masalah}

Perumusan masalah pada makalah ini yaitu "Bagaimana perilaku pengguna Sistem Informasi Pengelolaan Nilai Rapor yang telah diterapkan berdasarkan metode UTAUT".

\section{Menentukan Responden}

Populasi dari penelitian ini berjumlah 42 orang. Sampel untuk penelitian diambil dari keseluruhan populasi yang ada (sampling jenuh) yakni seluruh guru yang menggunakan sistem informasi pengelolaan nilai rapor.

\section{Melakukan Observasi}

Dalam makalah ini penulis melakukan pengamatan langsung di lingkungan SMPN 1 Tualang yaitu dengan melihat guru sebagai pengguna sistem mengoperasikan sistem informasi pengelolaan nilai rapor. 


\section{Menentukan Hipotesis}

Adapun hipotesis yang akan dilakukan adalah sebagai berikut:

Tabel 1. hipotesis

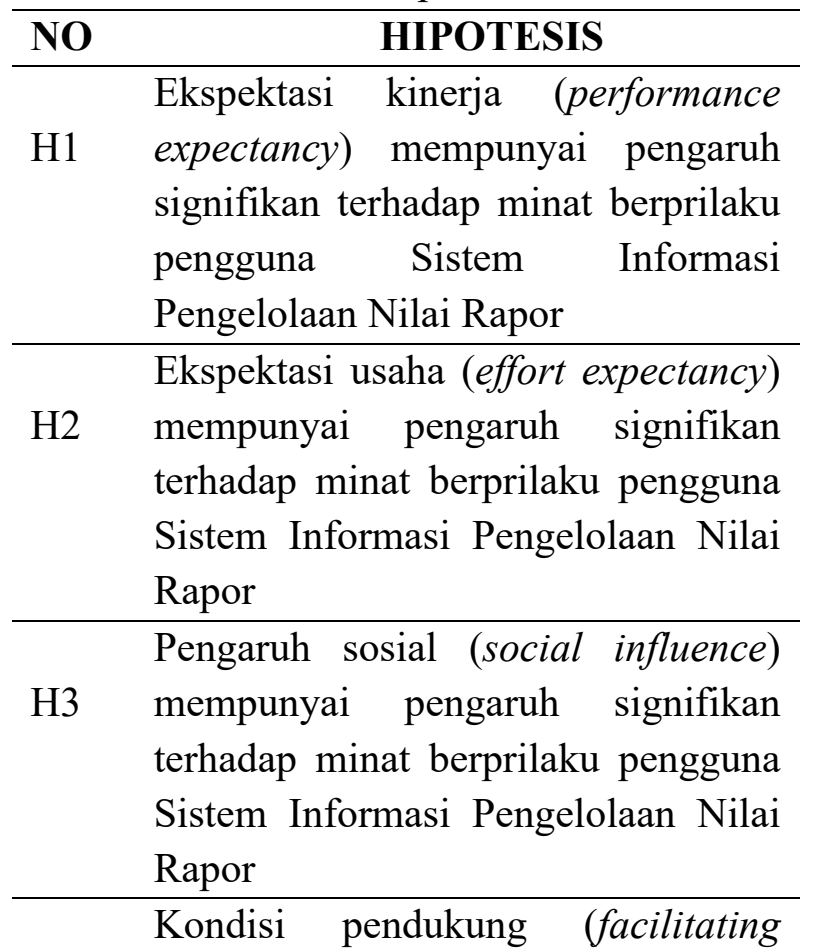

H4 condition) mempunyai pengaruh signifikan terhadap minat berprilaku pengguna Sistem Informasi Pengelolaan Nilai Rapor

Jenis kelamin mempunyai pengaruh

H5 signifikan dalam hubungan antara performance expectancy terhadap behavioral intention Jenis kelamin mempunyai pengaruh

H6 signifikan dalam hubungan antara effort expectancy terhadap behavioral intention

Jenis kelamin mempunyai pengaruh

H7 signifikan dalam hubungan antara social influence terhadap behavioral intention

Usia mempunyai pengaruh signifikan

H8 dalam hubungan antara performance expectancy terhadap behavioral intention

H9 hubungan antara effort expectancy

\begin{tabular}{|c|c|}
\hline & ntion \\
\hline H10 & $\begin{array}{l}\text { Usia mempunyai pengaruh signifikan } \\
\text { dalam hubungan antara social } \\
\text { influence terhadap behavioral } \\
\text { intention }\end{array}$ \\
\hline H11 & $\begin{array}{l}\text { Usia mempunyai pengaruh signifikan } \\
\text { dalam hubungan antara facilitating } \\
\text { condition terhadap behavioral } \\
\text { intention }\end{array}$ \\
\hline H12 & $\begin{array}{l}\text { Pengalaman mempunyai pengaruh } \\
\text { signifikan dalam hubungan antara } \\
\text { effort expectancy terhadap behavioral } \\
\text { intention }\end{array}$ \\
\hline H13 & $\begin{array}{l}\text { Pengalaman mempunyai pengaruh } \\
\text { signifikan dalam hubungan antara } \\
\text { social influence terhadap behavioral } \\
\text { intention }\end{array}$ \\
\hline H14 & $\begin{array}{l}\text { Pengalaman mempunyai pengaruh } \\
\text { signifikan dalam hubungan antara } \\
\text { facilitating condition terhadap } \\
\text { behavioral intention }\end{array}$ \\
\hline
\end{tabular}

\section{Menyebarkan Kuesioner}

Penulis menyebarkan kuisioner yang berisi pertanyaan-pertanyaan secara tertulis untuk diisi oleh sumber informasi. Kuesioner disebarkan kepada guru SMPN 1 Tualng. Pernyataan-pernyataan kuisioner berdasarkan kepada emapat konsep yang ada pada metode UTAUT yaitu ekspektasi kinerja (performance expectancy), ekspektasi usaha (effort expextancy), pengaruh sosial (social influence), kondisi pendukung (facilitating conditions).

\section{Tahap Analisis Perilaku Pengguna}

Tahap analisis adalah menganalisa data-data yang telah didapatkan dari pengolahan data, sehingga dapat ditarik kesimpulan dari penelitian yang dilakukan.

Pada model UTAUT terdapat 4 (empat) variabel dan 4 (empat) moderator yaitu Performance expectancy, effort expectancy, social influence dan facilitating conditions 
yang dimoderatori oleh gender, age, experience dan voluntariness of use. Namun pada penelitian ini yang digunakan 4 (empat) variabel dan 3 (tiga) moderator yaitu gender, age, dan experience. Berikut modifikasi model UTAUT yang digunakan dalam penelitian ini dapat dilihat pada gambar 3 .

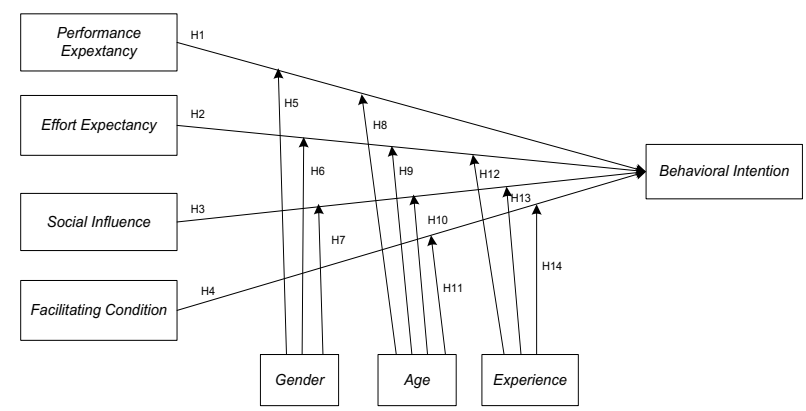

Gambar 3. Modifikasi UTAUT

\section{Membuat Kesimpulan}

Tahap ini mengumpulkan dan menyusun setiap tahapan yang telah dilakukan serta menyusun penemuan-penemuan berdasarkan batasan penelitian yang ada, dan membuat kesimpulan hasil penelitian yang sesuai dengan hipotesis yang diajukan serta menyajikan saran karena penelitian yang dibuat memiliki keterbatasan ataupun asumsi-asumsi.

\section{HASIL}

\section{Analisis Kondisi Saat Ini}

Sistem Informasi Pengelolaan Nilai Rapor merupakan sistem informasi yang bertujuan untuk mempermudah guru dalam mengelola nilai rapor siswa. Model Kurikulum 2013 mengharuskan guru membuat dua nilai seperti nilai besar (1-100) dan nilai kecil (1-4), dengan sistem ini guru hanya mengolah atau menginput nilai besar nya saja seperti nilai pengetahuan, keterampilan dan perilaku lalu sistem yang akan memproses nilai tersebut menjadi nilai kecil. Berikut ini merupakan halaman login dari sistem informasi pengelolaan nilai rapor.

Sistem Informasi Pengelolaan Nilai Rapor digunakan oleh semua guru, namun setiap guru memiliki tampilan menu yang berbeda sesuai dengan tugas dan tanggung jawabnya masingmasing. Pada sistem ini terdapat 3 hak akses sitem yaitu:

\section{Admin}

Pada beranda admin terdapat fitur untuk menambahkan data siswa, data guru, matapelajaran, ekskul, nilai rapor dan dapat mengganti username dan passsword user.

2. Wali Kelas

Pada beranda walikelas terdapat fitur untuk melihat data siswa, menginputkan absen, ekskul, nilai dan mencetak rapor siswa.

3. Guru

Pada beranda guru terdapat fitur untukmenginputkan nilai siswa sesuai matapelajaran yang diajarkan oleh guru tersebut.

Adapun langkah-langkah penginputan nilai kedalam sistem informasi pengelolaan nilai rapor yaitu:

1. Guru login kedalam sistem informasi pengelolaan nilai rapor menggunakan username dan password.

2. Guru memilih matapelajaran yang akan diinputkan nilai.

3. Guru menginputkan nilai siswa yang terdiri dari nilai pengetahuan, keterampilan dan sikap.

4. Walikelas login kedalam sistem

5. Waikelas melihat nilai yang telah diinputkan guru matapelajaran. Jika nilai kosong walikelas akan memberitahu guru yang bersangkutan agar segera menginputkan nilai

6. Admin mencetak rapor siswa.

\section{Deskripsi Karakteristik Responden}

Responden yang dilibatkan dalam penelitian ini sebanyak 46 responden. Responden merupakan 42 orang guru yang mempunyai hak 
akses pada sistem informasi pengelolaan nilai rapor dan 4 orang staff kurikulum yang bertanggung jawab atas sistem informasi pengelolaan nilai rapor. Subjek diminta untuk men-cheklist dengan bebas setiap pernyataan yang berjumlah 20 pernyataan.

Gambaran umum 42 responden ditunjukkan pada tabel berikut:

Tabel 2. Gambaran umum 42 responden

\begin{tabular}{lcc}
\hline Deskripsi & Frekuensi & Persentase \\
\hline Jenis Kelamin & & \\
\hline Laki-Laki & 5 & $11,9 \%$ \\
\hline Perempuan & 37 & $88,1 \%$ \\
\hline Usia & & \\
\hline $20-29$ & 4 & $9,5 \%$ \\
\hline $30-39$ & 5 & $14,3 \%$ \\
\hline $40-49$ & 19 & $45,2 \%$ \\
\hline$>50$ Tahun & 14 & $31,0 \%$
\end{tabular}

\begin{tabular}{lll}
\hline Pengalaman & & \\
\hline$<2$ Tahun & 11 & $26,2 \%$ \\
\hline $2-3$ Tahun & 16 & $38,1 \%$ \\
\hline$>3$ Tahun & 15 & $35,7 \%$ \\
\hline
\end{tabular}

\section{Hasil Uji Validitas dan Reliabilitas}

Pengujian dilakukan dengan cara membandingkan nilai kolerasi product moment atau biasa disebut dengan $r$ tabel dengan $r$ hitung, dimana $r$ hitung harus lebih besar dari $r$ tabel. Apabila $r$ hitung lebih besar dari $r$ tabel maka data tersebut dinyatakan valid dan angket dapat digunakan dalam analisis berikutnya [6].

Dalam penelitian ini dengan jumlah sampel 46 dan taraf signifikan 5\% didapat $\mathrm{r}$ tabel = 0,291. Tabel 2 menunjukkan bahwa masingmasingitem pernyataan mempunyai nilai $r$ hitung $>r$ tabel, jadi dapat disimpulkan bahwa masing-masing item pernyataan dinyatakan valid. Sedangkan untuk reliabilitas item pernyataan adalah reliabel sesuai dengan standarisasi Cronbach Alpha, nilai lebih besar dari 0,60 .

\section{Uji Hipotesis}

Hasil pengujian hipotesis dapat dilihat sebagai berikut:

\section{A. Uji T}

Berdasarkan hasil Uji $\mathrm{T}$ menunjukkan bahwa:

1. Hipotesis $\mathrm{H} 1$ diterima, bahwa performance expectancy memberi pengaruh yang signifikan pada behavioral intention, responden mempunyai anggapan bahwa pengunaan sistem informasi pengelolaan nilai rapor dapat menolongnya untuk mendapatkan keuntungn-keuntungan kinerja dipekerjaannya.

2. Hipotesis $\mathrm{H} 2$ diterima, bahwa effort expectancy atau tingkat kemudahan memberikan pengaruh yang signifikan pada behavioral intention,

3. Hipotesis $\mathrm{H} 3$ ditolak, bahwa social influence tidak memiliki pengaruh yang signifikan pada behavioral intention.

4. Hipotesis H4 diterima, bahwa facilitating condition mempunyai pengaruh yang signifikan terhadap behavioral intention. Dimana pengguna percaya dengan adanya kondisi yang membantu dalam menggunakan sistem informasi pengelolaan nilai rapor akan lebih memudahkan dalam pengaplikasian sistem pengelolaan nilai rapor.

5. Hipotesis H5 ditolak, Dari hasil uji hipotesis diketahui bahwa moderator gender terhadap variabel performance expectancy tidak mempunyai pengaruh signifikan terhadap perilaku penggunaan Sistem Informasi Pengelolaan Nilai Rapor

6. Hipotesis 6 diterima, Dari hasil uji hipotesis diketahui bahwa moderator gender terhadap variabel effort expectancy mempunyai pengaruh signifikan terhadap perilaku penggunaan Sistem Informasi Pengelolaan Nilai Rapor. 
7. Hipotesis 7 ditolak, Dari hasil uji hipotesis diketahui bahwa moderator gender terhadap variabel social influence tidak mempunyai pengaruh signifikan terhadap perilaku penggunaan Sistem Informasi Pengelolaan Nilai Rapor.

8. Hipotesis 8 diterima, Dari hasil uji hipotesis diketahui bahwa moderator age terhadap variabel performance expectancy mempunyai pengaruh namun tidak signifikan terhadap perilaku penggunaan Sistem Informasi Pengelolaan Nilai Rapor.

9. Hipotesis 9 ditolak, Dari hasil uji hipotesis diketahui bahwa moderator age terhadap variabel effort expectancy tidak mempunyai pengaruh signifikan terhadap perilaku penggunaan Sistem Informasi Pengelolaan Nilai Rapor.

10. Hipotesis 10 diolak, Dari hasil uji hipotesis diketahui bahwa moderator age terhadap variabel social influence tidak mempunyai pengaruh signifikan terhadap perilaku penggunaan Sistem Informasi Pengelolaan Nilai Rapor.

11. Hipotesis 11 diterima, Dari hasil uji hipotesis diketahui bahwa moderator age terhadap variabel facilitating condition mempunyai pengaruh signifikan terhadap perilaku penggunaan Sistem Informasi Pengelolaan Nilai Rapor.

12. Hipotesis 12 diterima, Dari hasil uji hipotesis diketahui bahwa moderator experience terhadap variabel effort expectancy mempunyai pengaruh signifikan terhadap perilaku penggunaan Sistem Informasi Pengelolaan Nilai Rapor.

13. Hipotesis 13 ditolak, Dari hasil uji hipotesis diketahui bahwa moderator experience terhadap variabel social influence tidak mempunyai pengaruh signifikan terhadap perilaku penggunaan Sistem Informasi Pengelolaan Nilai Rapor.
14. Hipotesis 14 ditolak, Dari hasil uji hipotesis diketahui bahwa moderator experience terhadap variabel facilitating condition tidak mempunyai pengaruh signifikan terhadap perilaku penggunaan Sistem Informasi Pengelolaan Nilai Rapor.

\section{B. Uji F}

Uji $\mathrm{F}$ dilakukan untuk melihat pengaruh semua variabel bebas secara bersama-sama terhadap variabel terikatnya. Pengujian dilakukan dengan membandingkan nilai $\mathrm{F}$ hitung dengan $\mathrm{F}$ tabel pada derajat kesalahan $5 \%$ dalam arti $(\alpha=0,05)$. Apabila nilai F hitung $>\mathrm{F}$ tabel maka variabel bebasnya secara bersama-sama memberikan pengaruh yang positif terhadap variabel terikat. Berikut penjelasan uji $\mathrm{F}$ dapat dilihat pada Tabel 8:

\begin{tabular}{|l|r|r|r|c|c|}
\hline $\begin{array}{c}\text { Mo } \\
\text { del }\end{array}$ & $\begin{array}{c}\text { Sum of } \\
\text { Squares }\end{array}$ & df & $\begin{array}{c}\text { Mean } \\
\text { Square }\end{array}$ & F & Sig. \\
\hline $\begin{array}{l}\text { Regre } \\
\text { ssion } \\
\text { Resi } \\
\text { dual } \\
\text { Total }\end{array}$ & 120,983 & 4 & 30,246 & 16,032 &, $000^{\mathrm{b}}$ \\
6903 & 37 & 1,887 & & \\
\hline
\end{tabular}

Dari output didapat F hitung 16,032, F tabel dicari pada signifikan 0,05 dengan derajat kebebasan df $1=\mathrm{k}-1 \quad(5-1=4)$, df $2=\mathrm{n}-\mathrm{k}-1$ (424-1= 37), maka diperoleh $\mathrm{F}$ tabel $=2,626$. Sehingga kesimpulannya bahwa Performance expectancy, effort expectancy, social influence, facilitating condition secara bersama-sama berpengaruh signifikan terhadap minat berprilaku pengguna Sistem Informasi Pengelolaan Nilai Rapor.

\section{Uji Koefisien Determinasi}

Tujuan pengujian koefisien determinasi untuk mengetahui seberapa besar kemampuan variabel independen menjelaskan variabel dependen. Nilai $\mathrm{R}^{2}$ berkisar antara 0 dan 1 atau $0 \leq \mathrm{R}^{2} \leq 1$.

Dari hasil pengujian dapat disimpulkan bahwa $R$ square $\left(\mathrm{R}^{2}\right)$ menunjukkan koefisien 
determinasi. Pada uji koefisien Determinasi tanpa moderator didapatkan nilai $\mathrm{R}^{2}$ ialah sebesar 0,634. Hal ini berarti variabel bebas yang diamati mempunyai hubungan yang kuat dengan variabel terikat. Dengan persentase performance expectancy, effort expectancy, social influence, dan facilitating condition terhadap behavioral intention sebesar 63,4\% sedangkan $36,6 \%$ dipengaruhi oleh variabel lainnya yang tidak diukur pada penelitian ini.

Pada pengujian determinasi dengan moderator didapatkan nilai $\mathrm{R}^{2}$ yang didapat ialah sebesar 0,790. Hal ini berarti persentase variabel moderator yang diamati mempunyai hubungan yang kuat dengan variabel bebas dan variabel terikat dengan persentase sebesar $79,0 \%$.

\section{Perhitungan $\boldsymbol{G A P}$}

Perhitungan gap untuk persepsi dan ekspektasi bertujuan untuk dapat mengetahui nilai kesenjangan antara kenyataan yang diterima dengan harapan dari pihak sekolah. Berikut hasil dari perhitungan gap:

Tabel 3. Perhitungan gap

\begin{tabular}{clccc}
\hline No & $\begin{array}{l}\text { Variabel } \\
\text { UTAUT }\end{array}$ & $\begin{array}{c}\text { Kenya } \\
\text { taan }\end{array}$ & $\begin{array}{c}\text { Hara } \\
\text { pan }\end{array}$ & Gap \\
\hline 1 & $\begin{array}{l}\text { Ekspektasi } \\
\text { Kinerja }\end{array}$ & 2,7 & 3,6 & \\
\hline 2 & $\begin{array}{l}\text { Ekspektasi } \\
\text { Usaha }\end{array}$ & 2,7 & 3,3 & $-0,9$ \\
\hline 3 & Pengaruh & 3,3 & 3,4 & \\
& Sosial & & & $-0,1$ \\
\hline 4 & Fasilitas & 2,8 & 3,5 & \\
& $\begin{array}{l}\text { yang } \\
\text { Mendukung }\end{array}$ & & & $-0,7$ \\
\hline
\end{tabular}

Dari tabel diatas tampak jelas bahwa semua nilai variabel bernilai negatif, ini artinya semua variabel Sistem Informasi Pengelolaan Nilai Rapor pada SMPN 1 Tualang belum memuaskan karena belum memenuhi keinginan pihak sekolah. Terdapat Jarak 0,9, 0,6, 0,1 dan 0,7 pada variabel ekspektasi kinerja, ekspektasi usaha, pengaruh social dan kondisi yang memfasilitasi antara harapan pihak sekolah dengan kondisi saat ini. Gap terbilang cukup besar Sehingga dapat ditarik kesimpulan bahwa pengimplementasian Sistem Informasi pengelolaan Nilai Rapor belum sesuai dengan harapan dari pihak sekolah .

\section{KESIMPULAN}

1. Berdasarkan 4 variabel yang terdapat pada UTAUT, didapatkan faktor-faktor yang paling mempengaruhi minat perilaku pengguna yaitu effort expectancy sebesar 68,5\%, kemudian facilitating conditions sebesar $62,7 \%$ dan performance expectancy sebesar 56,6\%. Sedangkan variabel social influence tidak berpengaruh terhadap minat perilaku pengguna.

2. Berdasarkan variabel moderator gender ditemukan bahwa gender memiliki pengaruh terhadap minat berperilaku pengguna pengguna sebesar $64,9 \%$ apabila sistem sistem informasi pengelolaan nilai rapor mudah untuk digunakan. Kemudian berdasarkan variabel moderator age ditemukan bahwa age memiliki pengaruh terhadap minat berperilaku pengguna sebesar $65,0 \%$ apabila sistem informasi pengelolaan nilai rapor dapat meningkatkan kinerja pengguna dan jika tersedianya fasilitas untuk mendukung penggunaan sistem. Sedangkan berdasarkan variabel moderator experience ditemukan bahwa moderator experience memiliki pengaruh terhadap minat berperilaku pengguna sebesar $69,6 \%$ apabila sistem informasi pengelolaan nilai rapor mudah untuk digunakan.

3. Hasil dari kesenjangan antara harapan pihak sekolah dan kenyataan yang diterima pengguna ditemukan bahwa sistem informasi pengelolaan nilai rapor belum sesuai dengan harapan dari pihak sekolah 
dengan nilai GAP sebesar -0,9. Untuk mengatasi gap pihak sekolah harus melakukan evaluasi dan monitoring mengenai penerapan sistem informasi pengelolaan nilai rapor pada SMPN 1 Tualang.

\section{DAFTAR PUSTAKA}

[1] Venkatesh, V., Morris, M. G., Davis, G. B., \& Davis, F.D. (2003). User Acceptance of Information Technology: Toward a Unified View. MIS Quarterly.

[2] Jogiyanto. "Sistem informasi keperilakuan". Andi Offset, Yogyakarta. 2008

[3] Rahmi, Y., Soedijono, B \& Fatta, H. A. "Analisis Penerapan Sistem Informasi Dosen dan Karyawan (SIMDOSKAR) Menggunakan Model Unified Theory of Acceptance and Use of Technology (UTAUT) terhadap Perilaku Pengguna”. Jurnal Informasi Interaktif Vol. 2, No. 2. hal 109-113. 2017.

[4] Butarbutar, F. T. S., \& Haryanto, Y. "Kajian Signifikansi Faktor Yang Mempengaruhi Penggunaan E-Learning Pada Siswa SMK Global Informatika Tangerang". Jurnal Resti. Vol. 1, No. 1. Hal 9-18. 2017.

[5] Sedana, I. G. N \& Wijaya, W. "Penerapan Model UTAUT Untuk Memahami Penerimaan dan Penggunaan Learning Management System Studi Kasus : Experential E-Learning of Sanata Dharma University". Journal of Information System. Vol. 5, No. 2. Hal 116. 2009.

[6] Ghozali, Imam. "Aplikasi Multivarite dengan SPSS.2011".Badan Penerbit Universitas Diponegoro,Semarang. 2011 